\title{
AECT's Technology in Instruction: Standards for college and university Learning Resources \\ Programs... \\ How viable for Australian institutions of higher education?
}

\author{
Richard Cornell \\ College of Education \\ University of Central Florida
}

\begin{abstract}
In the autumn of 1988 AECT (the Association for Educational Communications and Technology) will publish the second edition of a document which provides American colleges and universities with definitive standards to be applied to their learning resources programs and centres. The author, having spent eighteen months in Australia, is also one of the co-authors of the document, and in this article raises the question of applicability of the Standards to Australian institutions of higher education.
\end{abstract}

When I first saw dawn break over the campus of Riverina College of Advanced Education in Wagga Wagga, I knew I was in for the experience of a lifetime. It is now some sixteen years later and I still harbour significant mental and emotional images of what life was like at a "country college". Most of those images are good ones, even bordering on having been ecstatic, while a few others are not. Fortunately the onset of midsenility has favoured me and so, what negative thoughts I might have once had, now bathed in the light of years passing, are either totally obscured or put aside as having been a frivolous adventure in personal growth.

Having said all of the foregoing, I should add that, had I in hand a document such as our AECT Standards committee has developed, my time in Wagga could have been far more productive. 
Now then, what is this mystical 'document' about which reference is being made? How was work on it begun... what does it attempt to accomplish... and perhaps more importantly, would a work of this sort, obviously designed and intended for North American institutions of higher education be of any use to you in Australia? These answers follow.

\section{AECT's Standards: History and Context}

As far back as the late 50's, Dr Gene Ferris and others had been involved in the development of some sort of definitive standards which would assist college and university "audiovisual" directors in administering their various centres. Ferris' efforts did produce a modest document which served as a place to begin.

Following on those efforts, Dr. William Fulton in Oklahoma headed a national study funded by the Department of Audiovisual Instruction to extend and formalise the earlier work.

I was a working member of the Fulton Task Force from 1963-66 and from this group emerged a rating scale which, when one connected all of the value points, provided a linear depiction of one's institutional audiovisual health.

In the early 1970s there was an expressed need to provide the membership of AECT (formerly DAVI) with a far more substantial study of what a college or university learning resources program should consist. The committee toiled for several years and there were a number of different contributing authors. They often appeared to work either at crosspurposes or not in concert with each other and a fragmented product evolved. Unfortunately, it was never to see the light of publication.

During this time, I was a member of the national association's Board of Directors and, in fact, was working in Australia. By the time I returned to Florida in 1973, the field was still without any definitive standards. I wrote to Dr. Richard Gilkey, then-President of the association and lamented this fact. Almost by return mail, I found myself appointed as the Chair of what was then begun as AECT's "Task Force II-Postsecondary Standards".

It took nine years of extensive research, analysis of what had previously been accomplished on the project, and numerous writing sessions and meetings. Some were at the annual convention, others held later in the year at Jacksonville, Florida. Finally, in 1982, the First Edition of our document emerged, albeit published by the Task Force II group. It was entitled Standards for College and University Learning Resources Programs. One of your own associates, in fact the current editor of this journal, was one of the many who assisted us with the birth of this work.

The document contained three majors sections: Section I dealt with roles, objectives and purposes of a learning resources centre and its programs; 
Section II covered the specific instructional support services typical of a learning resources centre in terms of their scope, function, actual elements, specific standards relating to each element, as well as budget and administrative guidelines; Section III consisted of data formation and collection thereof, including instruments for doing so, a mechanism for publication of the data collected and a means through which the data collection might be monitored.

A five-part appendices contained (a) Learning Resources Program Profile, (b) an Institutional Check Sheet, (c) a Management Process Model, (d) a Self-Study Guide, and (e) a listing of the constituent members of the Council on Joint Secondary Education.

Almost as soon as our "baby" was birthed we realised that major revisions would be necessary. We had gone ahead with publication of the first edition, largely in response to hundreds of requests from the field to "... at least give us something... anything will be better than what we currently have".

It has taken an additional six years to bring the second edition to fruition. Its title: Technology in Instruction: Standards for College and University Learning Resources Programs. Its intent: as with the first edition, the purpose of the document is to provide both the Director of a Learning Resources Program and the college or university's chief administrators a management tool which will assist them in assessing and evaluating the degree and extent, both qualitatively and quantitatively, to which their own programs compare with established norms.

Perhaps the significant set of words herein is "established norms" for such have never before been available to the extent that they are at present. College and university libraries across the nation (and the world) have had a long and distinctive history of providing for their constituents very precise norms as to how many volumes the collection should have, how many square feet per reader should there be, how much of the institution's educational budget should be set aside for the library and so on. Not so with the learning resources programs... at least, not so until now!

The "norms" to which we have alluded previously concern themselves with consensus as to what should be and also, in terms of an institution's size and scope (read mission), they are tied into the Carnegie Classification for institutions of higher education. That is, institutions differ in their missions as well as their sizes and major clienteles. The Carnegie system recognises these differences.

The new Standards also hinge themselves to this system so that, no matter what your size or intent, there should be a means through which you can measure where you stand as relates to your learning resources program. 


\section{The Standards of 1988: Their Content}

Technology In Instruction: Standards for College and University Learning Resources Programs contains a four-page introduction and is then followed by Parts I and II. A bibliography containing thirty-six entries is also included.

\section{Executive Summary: Verbatim Quote}

Right now, American colleges and universities have an opportunity to respond to the critical learning needs of the citizens of this country-and perhaps of the world.

Skilled and dedicated people await the challenge. The technology is available. Commitment and planning for better instruction remain untapped, however, in many of our colleges and universities.

This document addresses not only the tremendous technological tools available to improve instruction, but also the planning and commitment necessary to face these challenges and capitalise on this opportunity.

The scope of the standards affects the following:

- academic computer centre

- library

- mail distribution

- media service program

- publishing and printing services

- telecommunication department

- television unit

- many other support services

A unified strategic plan includes all of these areas. It focuses direction and scope on the needs of the students and recognises the role of faculty, administrators, alumni, and others in meeting learner needs.

These standards identify benchmarks in such a plan and are congruent with other standards, such as those developed by ACRL (Association of College and Research Libraries-a Division of the American Library Association). The real benefits of the book are closely focused on the institutions. Short-range benefits include:

- discovery of strengths and weaknesses in the campus learning resource program;

- professional development of the Learning Resources Program director and staff;

- increased awareness of users to Learning Resources Program services; and

- identification of program changes and improvements.

In the long run, the standards can benefit the institution in the following ways:

- improving service to faculty, staff, and students;

- strengthening faculty recruiting;

- providing a critical recruiting tool for potential students;

- increasing funds allocated to the learning resources program (especially if numerous separate departments comprise the Learning Resources Program); and 
- generating revenues through the sale of instructional materials to other institutions.

Still, the top priority of the standards ischange that promotes improved instruction - not maintenance of things as they are. As we discover new ways of meeting learner needs, the traditional solutions and structure may change dramatically. We support change, and challenge college and university leaders at all levels to reach for opportunities to excel" (Cornell, Spears and others, 1988).

\section{The Standards}

Part I looks first at overall institutional standards and their relationship to the Learning Resources Program (LRP). They seek to assess the degree to which the LRP supports the institution's instructional and research activities. While the standards acknowledge that the LRP is often called upon to support administrative functions of an institution, it should not do so at the expense of instruction and research.

This section suggests that if administrative activities are to require substantial support from the LRP there should be parallel financial support to conduct such activities, in addition to that required for the support of research and instruction! It concludes with mention that "the emphasis and efforts of each service of the Learning Resources Program is on quality of performance rather than quantity" (Cornell, Spears, et. al. 1988, p11).

A typical standard which appears in Section 1 Institutional Standards is:

1.2. The institution shall establish a policy statement for the Learning

Resources Program, including its relationship to other entities of the institution. This statement shall reflect the institution's concept of the role that the Learning Resources Program plays in accomplishing the goals and objectives of the institution.

The next section of Part I examines a critical part of the document as a whole: management. This is a new section which was not contained in the First Edition. The management standards are designed for both singleperson LRP's as well as those with multi-unit programs.

Implicit in the management standards is the director's ability to work with a wide range of staff, administrators, and users. From an organisational standpoint, however, only the director of the LRP is held responsible for the program and its resources. While others may play important roles therein, without good management (director's role) the program has little chance of success. Leadership qualities play a major role in evaluation of the director.

A typical example of one of the management standards is: 
2.1.1 Knowledge. The director of the Learning Resources Program has a well rounded in-depth knowledge of learning resources and demonstrated knowledge of management.

Three levels of performance criteria are then provided. The Operational Level, for example, being the minimum, indicates that the director possess the terminal degree with training in administration and management science, learning and communications theory, systems analysis and design, curriculum and instructional development, and information science.

Flexibility is demonstrated within this standard when it refers to the "terminal degree" as being commensurate with that expected of faculty at the institution, ie. if it is a small tertiary college in the Riverina, a doctorate may not be "commensurate" with those held by others on the faculty.

The management standard for Knowledge adds two additional levels above Operational (Minimal Criteria) - Leadership Level (Basic Criteria) which asks that the director continue to increase his or her knowledge of communications and group dynamics; and Innovative Level (Advanced Criteria) in which the director has in-depth knowledge of some particular facet of the LRP for which he or she has national recognition.

These same levels appear throughout the document with each succeeding level adding to the degree of expertise or capability beyond the one prior to it. Fortunately, with the use of the Carnegie Classification System being applied to the evaluation process, it is possible for a small institution or one with a single focus, to still achieve an Innovative Level across the entire learning resources program for it is what the institution does with its available resources that is the critical distinction, not how large the institution might be.

It is not the author's intent to subject the reader to an analysis of each section of the document item-by-item. Rather, it is to provide you with the overall flavour of the Standards and to indicate that, once they are available from AECT, you may well wish to obtain a copy of them.

To perhaps whet your appetites somewhat, see the Table of Contents which have been reproduced on the following page. I shall then conclude with some observations as to the efficacy of using the Standards in Australian college and university learning resources programs.

\section{Implications for Australian Colleges and Universities}

I began this article with the retrospective wish that, had I available a copy of the Standards document things might well have gone far more smoothly than they did back in 1972-73. Of course, one could, if they wished, lay blame for not achieving all that one envisioned, directly at the feet of those in the administrative leadership role. Such can hardly be 
stated as the case for all of us, no matter where we are placed within the institutional scheme, must share either the collective kudos or lack of them when things turn awry.

\section{The Standards: Table of Contents}

Fonrard
Freface
Executive Summary
Introduction
Leaming Resources Frogram Definition
Furpose
Scope
Benefits
FART I: THE STANDAFDS
Institutional Standards
Management Standards
Director, LFF Frogram
Knowledge
Attitude
Skill
LFF, Info. Structure
Goals and Objectives
Flans
Organization
Folicies and Frocedures
Communication
Evaluation
LFF, Financial Structure
Budget
Current Value
Frogram Standards
Designand Development Function
Instructional Design
Faculty Development

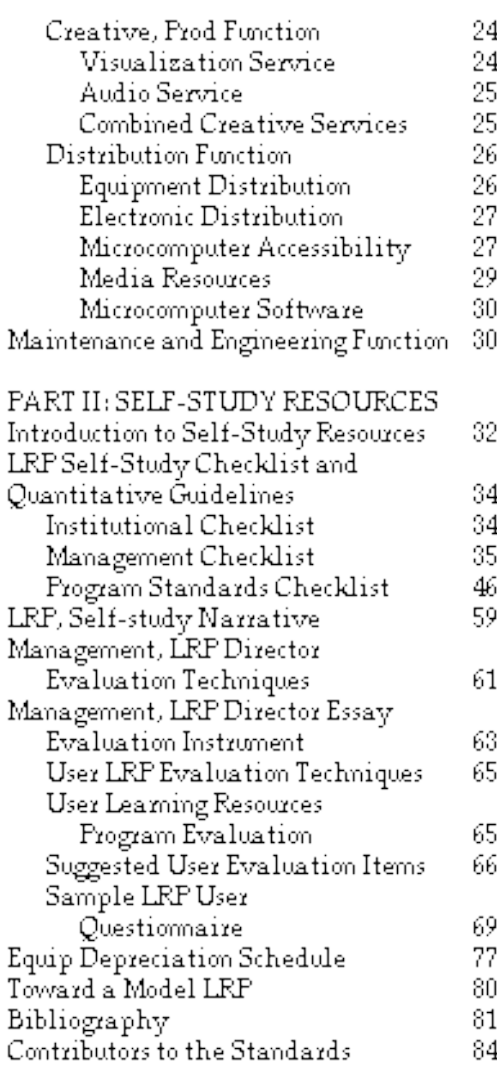

Simply put, the Standards document contains ample means through which any institution can formulate a long-range plan for excellence within its learning resources program. For the first time in the history of the profession, there now appear specific sets of criteria which relate to the proactive role of the LRP's director. This should prove a real boon to those administrators across the globe who have sometimes little more than a vague understanding of the direction which should be taken by their LRP directors.

For example, the concept of the "5\% turndown request rate", in and of itself a controversial notion, announces clearly to all within the institution that, if the LRP cannot satisfy 95\% of the requests made of it, there is justification for expansion of that segment of the program which cannot meet this criterion level. This "expansion" does not portend an automatic 
increase in budgetary request levels however, because of necessity, it must involve substantial back-up information which will justify such a request.

There is a section within Part II of the Standards which, for the first time, provides the director of the LRP with a cost analysis model, including depreciation schedules and then, having figured such factors as age of equipment and materials, plus cost of production of materials and their shelf-life value, can then arrive at a real price valuation of the entire learning resources program. This section alone should prove invaluable to the director who has been asked by his administration to justify the costbenefit ratio of the program as a whole!

From where I have sat, both in the United States and in Australia, it is my feeling that the Standards can prove of great value to the innovative director of any Australian college or university. Note the emphasis is placed on innovative. Clearly, the LRP director who seeks naught but the status quo will find in the Standards their death knell, for they are very much accountability based. This applies, by the way, no matter what the country in which they are being used.

The matter of cultural bias is, from my standpoint, a moot one, given that while in Wagga, I performed basically many of the self-same tasks that had been expected of me in Orlando, Florida. If anything, because I feel that there still prevails a spirit of free inquiry and experimentation in your nation, the Australian colleges and universities may well have a better chance of really implementing the Standards than might their American counterparts-simply because within the American higher education system, far too much atrophy has been the case and the element of risktaking has been looked upon by various CEO's as not being academically acceptable ... nor desirable either!

To be innovative is risk taking! It takes gumption to digress from the mainstream, to forage ahead where few are willing to. There are still institutions within the United States who are willing to take the risks of actually seeking to improve their own learning resources programs, many of them. It is to them and to you in Australia, to whom this work has been dedicated. I wish each of you well, challenge you to consider the Standards and, even more, share them with your own academic CEOs. Then stand back and watch the fur fly... what more could an innovative director of learning resources want!

\section{References}

Cornell, R. A., Spears, R. and others (1981). Standards for College and University Learning Resources Programs. Washington, DC: AECT Task Force II, June. 
Cornell, R. A., Spears, R. and others (1988 [in press]). Technology in Instruction: Standards for College and University Learning Resources Programs. Washington, DC: AECT, 85pp.

Copies of the standard should be requested by writing to: Association for Educational Communications and Technology, 1126 Sixteenth Street, NW, Washington DC 20036 USA.

Author: Dr. Richard Cornell, born in Toronto, Canada, has been in Florida, off and on, for the past twenty-four years. Two years of the "off' were spent as Associate Director of the AACTE (American Association of Colleges for Teacher Education) Media Project while another eighteen months were spent as Acting Director of the Learning Resources Centre at the Riverina College of Advanced Education in Wagga.

He has travelled, lectured, and photographed in some 36 different countries with Asia the remaining continent which he has yet to experience. He has, however, been invited to spend three months as a lecturer, consultant during the summer of 1989 at the National Taiwan Normal University in Taipei.

Dr. Cornell has served on the Board of Directors of the Association for Educational Communications and Technology, been twice a nominee for its presidency, and is the current President of the International Division of AECT. He is, simultaneously, the Vice President for Liaison in the International Chapter of the National Society for Performance and Instruction.

He lectured at the University of New South Wales and at the Riverina Murray Institute of Higher Education in Wagga in August of 1988 as well as gave briefings to the pilots and flight attendants at Qantas Airways. This latter task is in conjunction with his current research on pilot fatigue on long haul flights for Eastern Airlines. He is also a past Summer Scholar for the Kennedy Space Centre site of the NASA liftoffs of the space shuttle.

Dr Cornell recalls with excitement, this past August when he renewed old friendships, both in Sydney and in Wagga Wagga, his favourite countrycity in the entire world!

Please cite as: Cornell, R. (1988). AECT's Technology in Instruction: Standards for college and university Learning Resources Programs ... How viable for Australian institutions of higher education? Australian Journal of Educational Technology, 4(2), 137-145.

http: / / www.ascilite.org.au / ajet / ajet4/ cornell.html 